\title{
Energy Saving and GHG Emission Reduction in a Micro-CCHP System by Use of Solar Energy
}

\author{
Ion V. Ion ${ }^{1}$, Gheorghe Ciocea ${ }^{2}$, Florin Popescu ${ }^{3},{ }^{1,3}$ “Dunarea de Jos” University of Galati, ${ }^{2}$ S.C. Termaexim S.A
}

\begin{abstract}
In this work, the reduction of greenhouse gas emission, and the energy saving by integrating solar collectors and photovoltaic panels in a Stirling engine based microcombined cooling, heating and power (mCCHP) system are studied. The mCCHP system consists of a natural gas Stirling CHP and an adsorber chiller. When the thermal outputs of the Stirling CHP and solar collectors are not sufficient to cover the heat demand for domestic hot water (DHW), heating/cooling, an auxiliary heating boiler starts to operate. The energy saving by using solar energy varies from $13.35 \%$ in December to $59.62 \%$ in April, in the case of solar collectors usage and from $7.47 \%$ in December to $28.27 \%$ in July, in the case of photovoltaic panels usage. By using solar energy the annual GHG emission decreases by $31.98 \%$ and the fuel cost reduction varies from $12.73 \%$ in December to $49.78 \%$ in June.
\end{abstract}

Keywords - micro CCHP, biomass heating boiler, solar energy, greenhouse gas emission, energy saving

\section{INTRODUCTION}

One of the 2020 Europe strategies known as "A resource efficient Europe" is to achieve the 20-20-20 targets, that means: reduction in EU greenhouse gases emissions of at least 20\% below 1990 levels; 20\% of EU energy consumption to come from renewable resources; $20 \%$ reduction in primary energy use to be achieved by improving energy efficiency [1].

Since buildings currently account for around $40 \%$ of total energy consumption in the EU, there is an important potential to reduce the greenhouse gas emissions through a more efficient use of energy and the use of energy from renewable sources in buildings. The Energy Performance of Buildings Directive 2010/31/EU (EPBD) promotes the improvement of the energy performance of buildings within the EU, taking into account outdoor climatic and local conditions, as well as indoor climate requirements and cost-effectiveness, and requires Member States to ensure that all new buildings will be so-called "nearly zero-energy buildings" by 2020 . The EU also promotes cogeneration based on a useful heat demand [2]. Besides the cogeneration systems, in the residential sector there is a growing interest in energy systems that involve the integration of renewable and conventional energy sources to produce electricity, heat and cooling (CCHP systems) simultaneously. In CCHP systems, the waste heat from the prime mover is used to satisfy the thermal demand (heating and cooling) achieving an energy efficiency level of around $80 \%$.

Due to the increasing price and low quality of centralized heating, many users are looking for more convenient options. To satisfy the users' requirements, the market offers a variety of small and micro energy conversion plants that deliver power, heating and cooling with lower greenhouse gas (GHG) emissions and high energy efficiency.

The use of a CCHP system for a remote residence is the best solution to satisfy the electricity and heat demands. In a traditional power plant, in addition to the large energy loss through the discharge of waste heat, energy losses occur in the transmission and distribution of electricity to individual users [3]. The micro CCHP systems are typically designed at less than $30 \mathrm{~kW}$ electric to produce both electricity and useable thermal energy onsite or near site, reducing the energy losses that occur during transmission and distribution.

As prime mover for the micro CCHP systems can be used internal combustion engines, gas turbines, steam turbines, organic Rankine engines, Stirling engines or fuel cells. The most commonly used prime movers for medium-scale (100$5000 \mathrm{~kW}$ ) applications and appropriate for commercial buildings are reciprocate internal combustion engines, because they have an almost flat efficiency curve above $30 \%$ of the nominal electrical power [4]. The advantages of using Stirling engines as the prime mover include higher energy efficiency, lower pollutant emissions and noise levels compared to internal combustion engines.

There are a lot of studies on the CCHP systems focused on the design, energy, environmental and economical analyses and optimization [5]-[12].

A mCCHP system was designed and built at "Dunarea de Jos" University of Galati within the framework of the project "Integrated micro CCHP -Stirling engine based on renewable energy sources for the isolated residential consumers from the South-East region of Romania (m-CCHP-SE)", granted by the EEA Financial Mechanism. The system was designed to operate only with renewable energy, biogas for Stirling engine and wood pellets for the auxiliary heating boiler. At the moment the system works on natural gas due to the unavailability of a biogas source. In order to reduce the fuel consumption and therefore the greenhouse gas emission photovoltaic panels and evacuated tube collectors were integrated in the system. This study deals with the environmental and economic analyses based on the energetic model of the mCCHP system. In the study, the operation of the prime mover (Stirling engine) matching the electric load was considered.

\section{SYSTEM DESCRIPTION}

The studied mCCHP system consists of a natural gas Stirling CHP, an adsorber chiller, a hot water storage tank, a cold water storage tank, an auxiliary heating boiler, solar collectors, photovoltaic panels, two cooling towers and pumps to circulate the fluids (Fig. 1). 
The characteristics of the main components of the system are given in Table I. The residential building equipped with the mCCHP system is $270 \mathrm{~m}^{2}$ and was designed to correspond to the A energetic class with the following average yearly specific consumptions: electricity $45 \mathrm{kWh} / \mathrm{m}^{2}$; heating $70 \mathrm{kWh} / \mathrm{m}^{2}$, cooling $20 \mathrm{kWh} / \mathrm{m}^{2}$ and domestic hot water $15 \mathrm{kWh} / \mathrm{m}^{2}$.

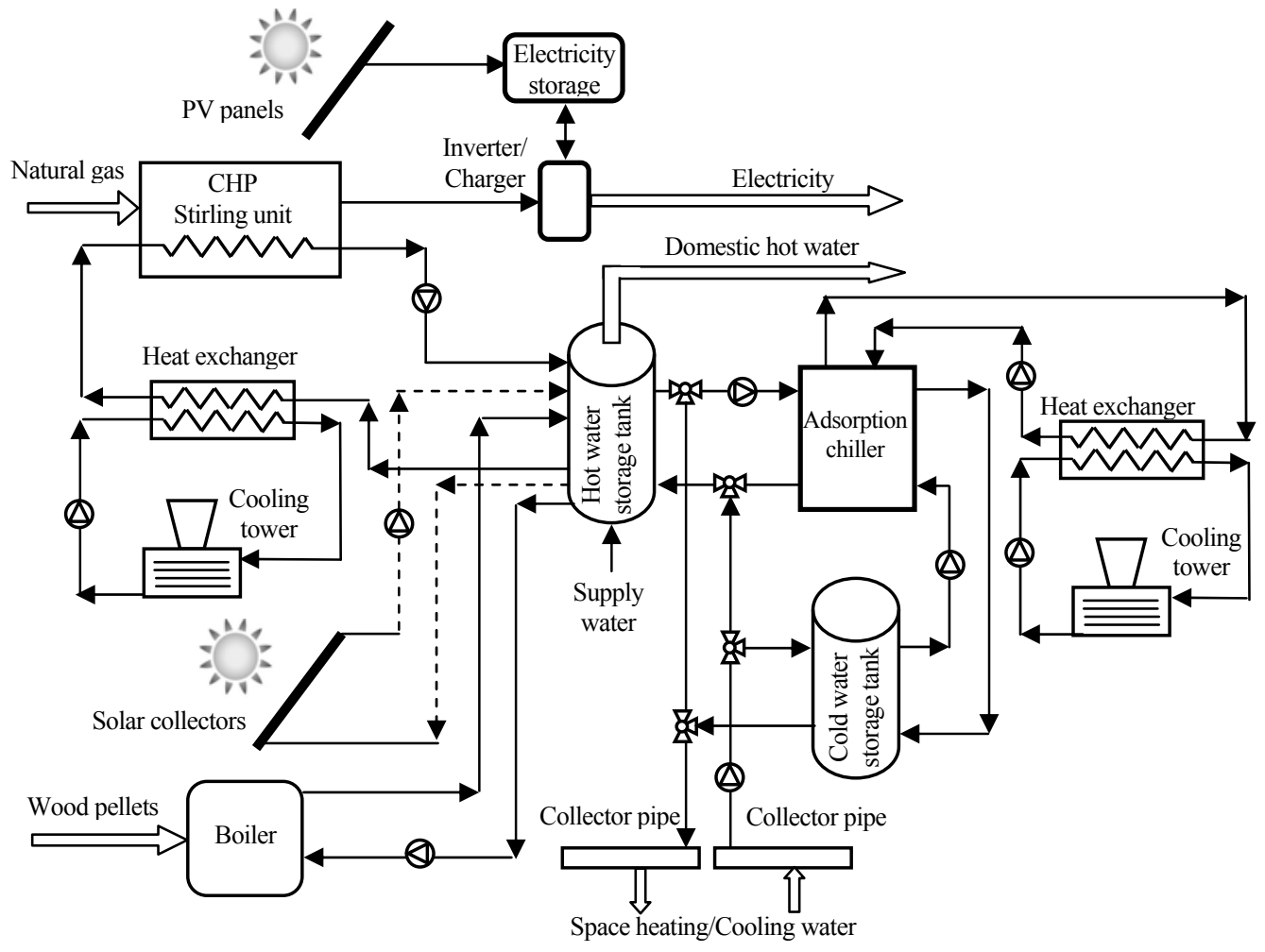

Fig. 1. Schematic diagram of the mCCHP system.

TABLE I

SYSTEM CHARACTERISTICS

\begin{tabular}{|c|c|}
\hline \multicolumn{2}{|l|}{ Stirling CHP (SOLO Stirling 161) } \\
\hline $\begin{array}{l}\text { Fuel type } \\
\text { Power output } \\
\text { Heat output } \\
\text { Heat to electricity output ratio }(\eta) \\
\text { Electrical efficiency }\left(\eta_{e l}\right) \\
\text { Overall efficiency } \\
\text { Hot water temperature } \\
\text { Inlet water temperature }\end{array}$ & $\begin{array}{l}\text { natural gas } \\
(1.1-8.9) \mathrm{kW} \\
(6-24.8) \mathrm{kW} \\
3 \\
26.8 \% \\
98.5 \% \\
(70-85)^{\circ} \mathrm{C} \\
60^{\circ} \mathrm{C} \\
\end{array}$ \\
\hline \multicolumn{2}{|l|}{ Auxiliary heating boiler } \\
\hline $\begin{array}{l}\text { Fuel type } \\
\text { Heat output } \\
\text { Hot water temperature } \\
\text { Water pressure } \\
\text { Thermal efficiency }\left(\eta_{b}\right)\end{array}$ & $\begin{array}{l}\text { biomass pellets } \\
30 \mathrm{~kW} \\
95^{\circ} \mathrm{C} \\
3 \mathrm{bar} \\
0.87\end{array}$ \\
\hline \multicolumn{2}{|l|}{ Photovoltaic panels } \\
\hline $\begin{array}{l}\text { PV module type } \\
\text { Nominal PV efficiency } \\
\text { PV temperature coefficient } \\
\text { Overall PV system efficiency }\left(\eta_{p v p}\right) \\
\text { Total aperture area }\left(A_{p v p}\right)\end{array}$ & $\begin{array}{l}\text { mono } \mathrm{Si} \\
14,0 \% \\
0,40 \% \\
12,5 \% \\
10 \mathrm{~m}^{2}\end{array}$ \\
\hline \multicolumn{2}{|c|}{ Adsorption chiller (SorTech AG ACS15) } \\
\hline $\begin{array}{l}\text { Cooling capacity } \\
\text { Coefficient of performance (COP) } \\
\text { Driving heat circuit } \\
\text { Chilled water circuit }\end{array}$ & $\begin{array}{l}(10-23) \mathrm{kW} \\
0,6 \\
(55-95)^{\circ} \mathrm{C} \\
(6-20)^{\circ} \mathrm{C}\end{array}$ \\
\hline
\end{tabular}

\begin{tabular}{|l|l|}
\hline $\begin{array}{l}\text { Heat rejection circuit } \\
\text { Power consumption }\end{array}$ & $(22-37)^{\circ} \mathrm{C}$ \\
\hline Solar collectors & $14 \mathrm{~W}$ \\
\hline Type & vacuum tube \\
Total aperture area $\left(A_{\text {sc }}\right)$ & $17.2 \mathrm{~m}^{2}$ \\
\hline
\end{tabular}

\section{Power, Heating And CoOling Consumptions}

There are many calculation methods used to estimate the energy requirements of buildings for electricity, domestic hot water, space heating and cooling. For EU Member States the Energy Performance of the Buildings Directive 2010/31/EU (EPBD) lays down requirements as regards the common general framework for a methodology to calculate the integrated energy performance of buildings and building units.

The calculation methods are divided into steady state calculation methods, which assume steady indoor and outdoor conditions for the calculation of the heat gains and losses in the building and dynamic methods which take into account climate variations and the effect of heat absorption and release inside the building [13].

One of the calculation methods which is applied the most due to its simplicity is the degree-days method to estimate the heating and cooling loads in buildings in winter and summer periods.

According to this method, the monthly heating and cooling loads are given by the following equations [13] and [14]:

- monthly heating load: 
$2012 / 10$

$$
Q_{h}=\frac{24 \cdot U \cdot A \cdot H D D}{\eta_{h}}[\mathrm{kWh}]
$$

- monthly cooling load:

$$
Q_{C}=\frac{24 \cdot U \cdot A \cdot C D D}{\eta_{c}}[\mathrm{kWh}]
$$

where: $A$ - total surface of walls, ceiling and floor, through which the energy is lost, $\left[\mathrm{m}^{2}\right] ; U$ - overall coefficient of heat losses of the building, $\left[\mathrm{kW} /\left(\mathrm{m}^{2} \cdot{ }^{\circ} \mathrm{C}\right)\right] ; H D D-$ monthly number of degree-days for heating, $\left[{ }^{\circ} \mathrm{C} \cdot\right.$ day $] ; C D D$ - monthly number of degree-days for cooling, $\left[{ }^{\circ} \mathrm{C} \cdot\right.$ day $] ; \eta_{h}$ - efficiency of the heating system; $\eta_{c}$ - efficiency of the cooling system.

The daily necessity of heat for domestic hot water can be estimated by the equation:

$$
Q_{d h w}=c_{p} \frac{G_{h w}^{N} \cdot N}{24 \cdot 3600}\left(t_{w h}-t_{w c}\right)[\mathrm{kWh}]
$$

where: $c_{p}$ - specific heat of water at constant pressure, $\left[\mathrm{kJ} /\left(\mathrm{kg} \cdot{ }^{\circ} \mathrm{C}\right)\right] ; G_{h w}^{N}$ - daily consumption of hot water per person, [1/person]; $N$ - number of people in the building; $t_{w h}$, $t_{w c}$ - temperatures of delivered hot water and water that is heated, respectively, $\left[{ }^{\circ} \mathrm{C}\right]$.

The monthly amount of electricity generated by Stirling $\mathrm{CHP}$ can be rewritten as:

$$
P_{S t}=\frac{\eta_{e l} \cdot F_{S} \cdot L H V}{3600}[\mathrm{kWh}]
$$

where: $F_{S}-$ monthly fuel consumption of Stirling CHP, $\left[\mathrm{Nm}^{3}\right] ; \eta_{e l}-$ electrical efficiency of Stirling CHP.

The monthly amount of electricity produced by the photovoltaic panels can be calculated as the following:

$$
P_{p v p}=A_{p v p} \cdot G_{T} \cdot \eta_{p v p}[\mathrm{kWh}]
$$

where: $A_{p v p}$ - total aperture area of photovoltaic panels, $\left[\mathrm{m}^{2}\right] ; G_{T}-$ monthly average radiation in plane of PVP array, $\left[\mathrm{kWh} / \mathrm{m}^{2}\right] ; \eta_{p v p}$ - overall PV system efficiency;

The monthly amount of heat produced by a Stirling engine is given by the equation:

$$
Q_{S t}=\eta \cdot P_{S t}[\mathrm{kWh}]
$$

where: $\eta$ - heat to electricity output ratio of Stirling engine.

The monthly amount of heat produced by the solar collectors is:

$$
Q_{S C}=\eta_{s C} \cdot A_{S C} \cdot G_{T}[\mathrm{kWh}]
$$

where: $A_{S C}-$ total aperture area of solar collectors, $\left[\mathrm{m}^{2}\right] ; \eta_{S C}$ - solar collector thermal efficiency. It is estimated by the following equation:

$$
\eta_{s c}=\eta_{0}-a_{1} \frac{T_{m}-T_{a}}{G}-a_{2} \frac{\left(T_{m}-T_{a}\right)^{2}}{G}
$$

where: $G$-total solar radiation in plane of solar collector, $\left[\mathrm{kW} / \mathrm{m}^{2}\right] ; \eta_{0}$-optical efficiency $\left(\eta_{0}=0.809\right) ; a_{1}, a_{2}$-thermal loss correction values $\left(a_{1}=1.37 \quad \mathrm{~W} /\left(\mathrm{m}^{2} \quad \mathrm{~K}\right)\right.$; $\left.a_{2}=0.0068 \mathrm{~W} /\left(\mathrm{m}^{2} \mathrm{~K}^{2}\right)\right) ; T_{m}-$ average collector temperature; $T_{a}-$ ambient temperature.

The monthly amount of heat produced by the heating boiler can be expressed as follows:

$$
Q_{b}=\frac{\eta_{b} \cdot F_{b} \cdot L H V}{3600}[\mathrm{kWh}]
$$

where: $\eta_{b}-$ boiler thermal efficiency; $F_{b}$ - monthly fuel consumption of the heating boiler, [kg].

Using the RETscreen 4 software [15] there were found, for Galati as location, the monthly average daily solar radiation in plane of PV panels and solar collectors $\left(\mathrm{kWh} / \mathrm{m}^{2} / \mathrm{d}\right)$, the monthly number of degree-days for heating and degree-days for cooling (Table II). With this data there can be calculated the monthly heating and cooling demands, the monthly amount of electricity produced by PV panels and heat produced by solar collectors. The results are shown in Figure 2 and Table III. The monthly total electricity demand (lighting, building and mCCHP consumption) varies slightly having an average value of $983 \mathrm{kWh}$ which corresponds to the specific consumption of $43.68 \mathrm{kWh} / \mathrm{m}^{2}$. The monthly domestic hot water demand was considered to be constant $(337.5 \mathrm{kWh})$.

TABLE II

WEATHER DATA FOR GALATI AS LOCATION [15]

\begin{tabular}{|l|c|c|c|c|}
\hline Month & $\begin{array}{c}\text { Monthly } \\
\text { average } \\
\text { temperature } \\
{\left[{ }^{\circ} \mathrm{C}\right]}\end{array}$ & $\begin{array}{c}\text { Monthly average } \\
\text { daily radiation in } \\
\text { plane of PVP } \\
{\left[\mathrm{kWh} / \mathrm{m}^{2} \cdot \mathrm{d}\right]}\end{array}$ & $\begin{array}{c}\text { Monthly } \\
\text { degree-days } \\
\text { for heating } \\
{\left[{ }^{\circ} \mathrm{C} \cdot \mathrm{d}\right]}\end{array}$ & $\begin{array}{c}\text { Monthly } \\
\text { degree-days } \\
\text { for cooling } \\
{\left[{ }^{\circ} \mathrm{C} \cdot \mathrm{d}\right]}\end{array}$ \\
\hline January & -1.7 & 2.77 & 611 & 0 \\
\hline February & -0.6 & 3.65 & 521 & 0 \\
\hline March & 5.0 & 4.34 & 403 & 0 \\
\hline April & 11.1 & 5.24 & 207 & 33 \\
\hline May & 16.7 & 5.53 & 40 & 208 \\
\hline June & 20.0 & 5.87 & 0 & 300 \\
\hline July & 21.7 & 5.91 & 0 & 363 \\
\hline August & 21.7 & 5.79 & 0 & 363 \\
\hline September & 17.8 & 5.26 & 6 & 234 \\
\hline October & 11.7 & 4.51 & 195 & 53 \\
\hline November & 5.0 & 2.98 & 390 & 0 \\
\hline December & 0.6 & 2.29 & 539 & 0 \\
\hline
\end{tabular}

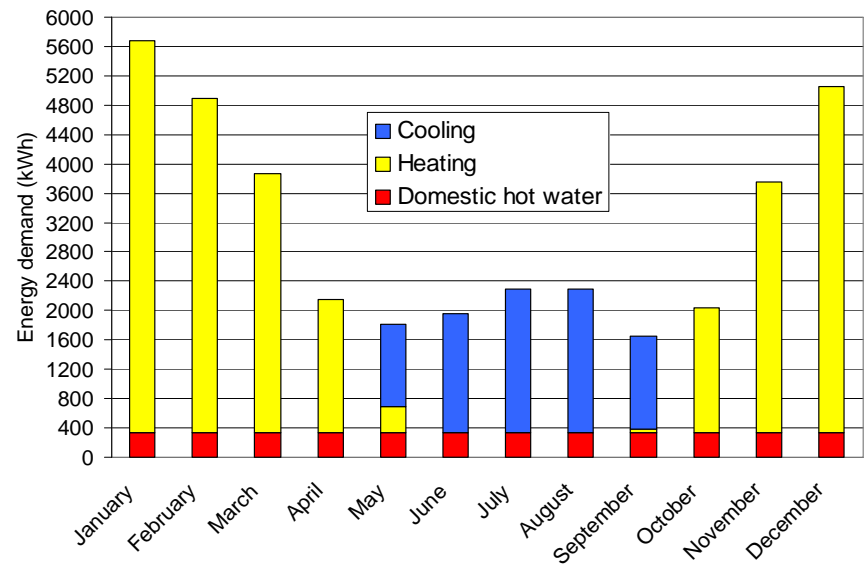

Fig. 2. The monthly demands for heating, domestic hot water and cooling. 
In April, May, September and October when neither heating nor cooling is necessary, the amount of heat produced by the solar collector and the Stirling CHP exceeds the total heat demand and a part of the heat generated by the Stirling CHP is rejected in a cooling tower.

TABLE III

MONTHLy ENERgy GeNERATED By PV PANElS AND SOlAR COLLECTORS

\begin{tabular}{|l|c|c|c|c|}
\hline Month & $\begin{array}{c}\text { Total } \\
\text { electricity } \\
\text { demand }[\mathrm{kWh}]\end{array}$ & $\begin{array}{c}\text { Total heat } \\
\text { demand }[\mathrm{kWh}]\end{array}$ & $\begin{array}{c}\text { Electricity } \\
\text { gained by PV } \\
\text { panels }[\mathrm{kWh}]\end{array}$ & $\begin{array}{c}\text { Heat gained by } \\
\text { solar collectors } \\
{[\mathrm{kWh}]}\end{array}$ \\
\hline January & 1188 & 5682.53 & 107.34 & 815.77 \\
\hline February & 1134 & 4895.21 & 127.75 & 970.90 \\
\hline March & 999 & 3862.94 & 168.18 & 1278.13 \\
\hline April & 891 & 2504.74 & 196.50 & 1493.40 \\
\hline May & 810 & 2933.82 & 214.29 & 1628.59 \\
\hline June & 810 & 3577.50 & 220.13 & 1672.95 \\
\hline July & 810 & 4257.90 & 229.01 & 1740.50 \\
\hline August & 810 & 4257.90 & 224.36 & 1705.16 \\
\hline September & 945 & 2917.19 & 197.25 & 1499.10 \\
\hline October & 1080 & 2615.76 & 174.76 & 1328.20 \\
\hline November & 1134 & 3749.22 & 111.75 & 849.30 \\
\hline December & 1188 & 5052.67 & 88.74 & 674.41 \\
\hline
\end{tabular}

\section{ENERGy SAVIng AND GREenhouse Gas EMISSION ASSESSMENT}

The use of solar energy to generate electricity and heat can save enough Stirling CHP and boiler power to cover the costs of solar collectors and photovoltaic panels in a few years. The Stirling engine uses natural gas with the lower heating value of $35500 \mathrm{~kJ} / \mathrm{Nm}^{3}$ and the heating boiler uses wood pellets with the lower heating value of $18000 \mathrm{~kJ} / \mathrm{kg}$. There are many works on the calculation of energy saving by using solar energy in heating and cooling systems [15], [16] and [17]. In this paper the percentages of energy saving by using solar collectors and photovoltaic panels are expressed as follows:

- energy saved by solar collectors:

$$
E S_{S C}=\frac{Q_{S C}}{Q_{h d}} 100[\%]
$$

- energy saved by photovoltaic panels:

$$
E S_{p v p}=\frac{P_{p v p}}{P_{e d}} 100[\%]
$$

where: $Q_{h d}-$ total heat demand, $[\mathrm{kWh}] ; P_{e d}-$ total electricity demand, [kWh].

By applying equations (10) and (11) to the studied system, the results given in Figure 3 are obtained. It can be observed that the energy saved by the photovoltaic panels varies from $7.47 \%$ in December to $28.27 \%$ in July and the energy saved by the solar collector varies from $13.35 \%$ in December to $59.62 \%$ in April.

There are many approaches to estimating the greenhouse gas emissions reduction from the energy systems [5], [6], [7], [15] and [18]. Using the GHG emission factors (Table IV) and knowing the energy consumptions of the mCCHP system in both cases with and without use of solar energy, the reduction of GHG emission can be calculated. The result of these calculations is shown in Figure 4. The total GHG amount in $\mathrm{CO}_{2}$ equivalent saved through use of solar energy in the $\mathrm{mCCHP}$ system in one year is about $4709 \mathrm{~kg} \mathrm{CO}$, which means a reduction by $31.98 \%$.

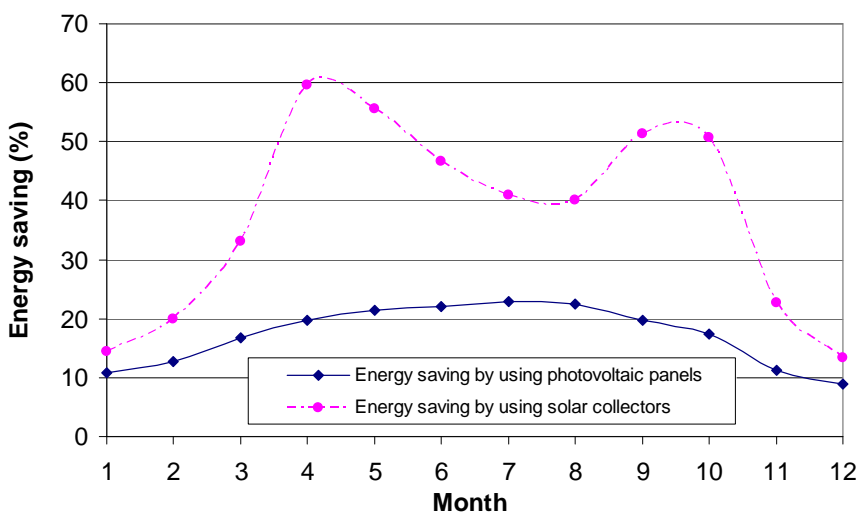

Fig. 3. Energy saving by using solar energy in the mCCHP system.

TABLE IV

GHG EMISSION FACTORS [18]

\begin{tabular}{|l|c|c|c|c|}
\hline Fuel type & $\begin{array}{c}\mathrm{CO}_{2} \text { emission } \\
\text { factor } \\
{[\mathrm{kg} / \mathrm{TJ}]}\end{array}$ & $\begin{array}{c}\mathrm{CH}_{4} \text { emission } \\
\text { factor } \\
{[\mathrm{kg} / \mathrm{TJ}]}\end{array}$ & $\begin{array}{c}\mathrm{N}_{2} \mathrm{O} \text { emission } \\
\text { factor } \\
{[\mathrm{kg} / \mathrm{TJ}]}\end{array}$ & $\begin{array}{c}\mathrm{GHG} \text { emission } \\
\text { factor } \\
{\left[\mathrm{t}_{\mathrm{CO} 2-\mathrm{eq}} / \mathrm{kWh}\right]}\end{array}$ \\
\hline Biomass & 0.0 & 0.3 & 4 & 0.027 \\
\hline Oil & 74100 & 10 & 0.6 & 0.268 \\
\hline Natural gas & 56100 & 5 & 0.1 & 0.202 \\
\hline
\end{tabular}

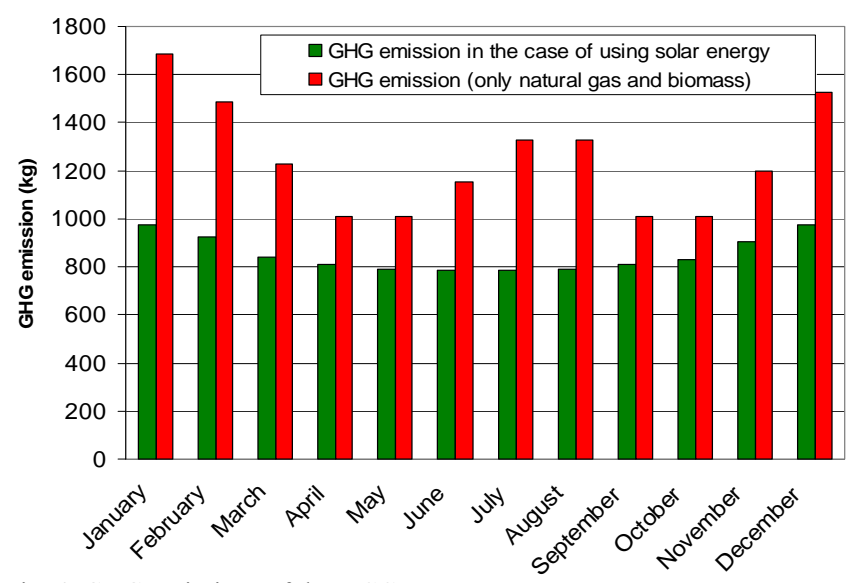

Fig. 4. GHG emissions of the mCCHP system.

The use of solar energy in the mCCHP system leads also to savings in fuel cost. Taking into account that in Romania the fuel costs are: $0.032 € / \mathrm{kWh}$ for wood pellets and the 0.028 $€ / \mathrm{kWh}$ for natural gas, the results of fuel cost reduction are shown in Figure 5. The fuel cost reduction varies from $12.73 \%$ in December to $49.78 \%$ in June. The total reduction of fuel cost is about $722 €$ /year. Considering a total cost of solar collectors and photovoltaic panels of $5000 €$ the results indicate that the capital cost can be recovered in less than 7 years. 


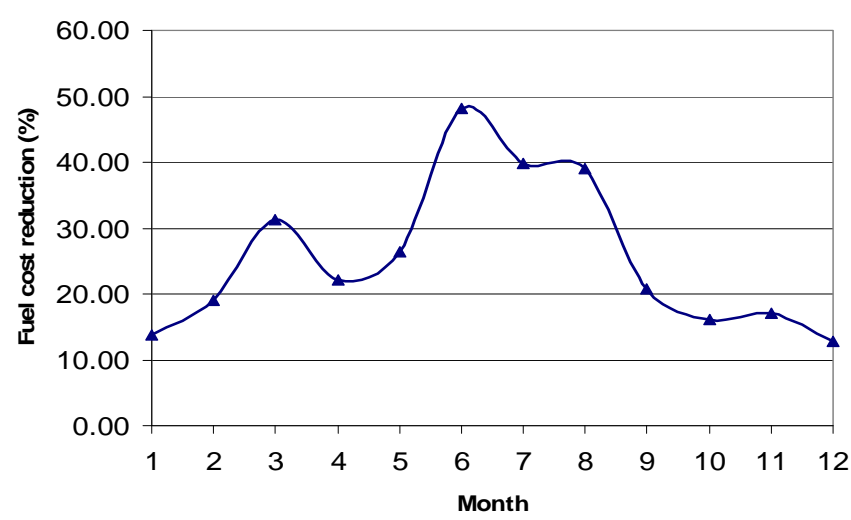

Fig. 5. Fuel cost reduction through use of solar energy.

\section{CONCLUSIONS}

The mCCHP system uses the primary energy more efficiently and economically than the traditional power plants and therefore it has lower greenhouse gas emission due to reductions in energy losses by transmission and distribution of energy to individual users and the use of renewable energy as a primary energy source.

In this paper a model was developed by using the technical characteristics of the system components and of the existing weather data to estimate the energy and carbon savings by using solar energy. Using the simplified approach, calcluations were made for the studied mCCHP system on: the energy saving, the GHG emission reduction and the fuel cost reduction obtained in a year by using solar energy. The total amount of energy saved is of $2060 \mathrm{~kW}_{\mathrm{el}} \mathrm{h}$ and of $15656 \mathrm{~kW}_{\mathrm{t}} \mathrm{h}$. The reduction of GHG emission is of $4709 \mathrm{~kg} \mathrm{CO}$-eq. The reduction of fuel cost is of $722 € /$ year.

\section{ACKNOWLEDGEMENTS}

The authors would like to acknowledge to EEA Financial Mechanism for financing the research on "Integrated micro CCHP -Stirling engine based on renewable energy sources for the isolated residential consumers from the South-East region of Romania (m-CCHP-SE)", under the contract No. RO-0054/2009.

\section{REFERENCES}

1. The EU climate and energy package. European Commission Brussels [Accessed 17.05.2012]. Available: http://ec.europa.eu/clima/ documentation/package/index en.htm

2. Directive 2004/8/EC of the European Parliament and of the Council of 11 February 2004. [Accessed 17.05.2012]. Available: http://eur-lex.europa. eu/LexUriServ/LexUriServ.do?uri=OJ:L:2004:052:0050:0060:EN:PDF

3. Mago P. J., Chamra L. M., Ramsay J. Micro-combined cooling, heating and power systems hybrid electric-thermal load following operation, Applied Thermal Engineering, vol. 30, Issues 8-9, 2010, p. 800-806.

4. Kavvadias, K .C., Tosios, A. P., Maroulis, Z. B. Design of a combined heating, cooling and power system: Sizing, operation strategy selection and parametric analysis, Energy Conversion and Management, vol. 51, N 4, 2010, p. 833-845.

5. Al-Sulaiman, F. A., Hamdullahpur, F., Dincer I. Greenhouse gas emission and exergy assessments of an integrated organic Rankine cycle with a biomass combustor for combined cooling, heating and power production, Applied Thermal Engineering, vol. 31, 2011, p. 439-446.

6. Chicco, G., Mancarella P. Assessment of the greenhouse gas emissions from cogeneration and trigeneration systems. Part I: Models and indicators, Energy, vol. 33, 2008, p. 410-417.

7. Fumo, N., Mago, P. J., Chamra, L. M. Emission operational strategy for combined cooling, heating, and power systems, Applied Energy, vol. 86,2009 , p. 2344-2350.
8. Fumo N., Chamra L. M. Analysis of combined cooling, heating, and power systems based on source primary energy consumption, Applied Energy, vol. 87, Issue 6, 2010, p. 2023-2030.

9. Zhai, H., Dai, Y. J., Wu, J.Y., Wang R. Z. Energy and exergy analyses on a novel hybrid solar heating, cooling and power generation system for remote areas, Applied Energy, vol. 86, Issue 9, 2009, p. 1395-1404.

10. Wu, D. W., Wang R. Z. Combined cooling, heating and power: A review, Progress in Energy and Combustion Science, vol. 32, Issues 5-6, 2006, p. 459-495.

11. Al-Salaymeh, A., Al-Rawabdeh, I., Emran, S. Economical investigation of an integrated boiler-solar energy saving system in Jordan, Energy Conversion and Management, vol. 51, 2010, p. 1621-1628.

12. Jaunzems, D., Veidenbergs, I. Small Scale Solar Cooling Unit in Climate Conditions of Latvia: Environmental and Economical Aspects, Scientific Journal of Riga Technical University-Environmental and Climate Technologies, vol. 4, 2010, p. 47-52.

13. Kokogiannakis, G. Support for the Integration of Simulation in the European Energy Performance of Buildings Directive, $\mathrm{PhD}$ Thesis, Glasgow: University of Strathclyde, 2008.

14. CIBSE (Chartered Institution of Building Services Engineers), CIBSE Guide A: Environmental design, 7th Edition, London, UK, 2006.

15. RETScreen 4; 2010. [Online]. Natural resources Canada - [Accessed 13.01.2011]. Available: http://www.retscreen.net

16. Thür, A., Furbo, S., Shah, L. J. Energy savings for solar heating systems, Solar Energy, 80, 2006, p. 1463-1474.

17. Calise, F., Palombo, A., Vanoli, L. Maximization of primary energy savings of solar heating and cooling systems by transient simulations and computer design of experiments, Applied Energy, vol. 87, 2010, p. 524-540.

18. 2006 IPCC Guidelines for National Greenhouse Gas Inventories, Volume 2 Energy. [Online]. [Accessed 13.01.2011]. Available: http://www.ipccnggip.iges.or.jp/public/2006gl/vol2.html

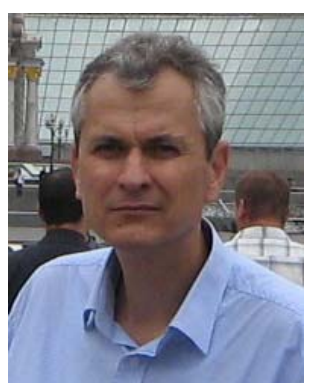

Ion V. Ion, $\mathrm{PhD}$. Eng., associate professor, "Dunarea de Jos" University of Galati, Mechanical Engineering Faculty, has joined the staff of Thermal Systems \& Environmental Engineering Department since $1990 . \quad \mathrm{He}$ defended his $\mathrm{PhD}$ thesis entitled "Steam boilers and air pollution control" in 1998. $\mathrm{He}$ participated in many national and European projects on applied thermodynamics, energy efficiency, renewable energy and air pollution control. For one year (2003-2004) he worked as NATO research fellow at University of Minho, Portugal in the field of solar thermal energy.

Address: "Dunarea de Jos" University of Galati, 47 Domneasca St., 800008 Galati, Romania. Phone: +40236 314463; Fax: +40236461353

E-mail: ion.ion@ugal.ro

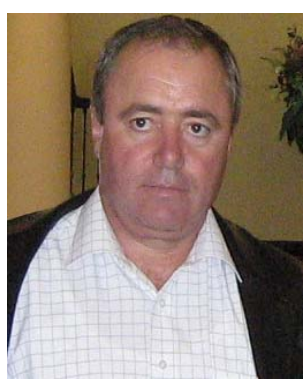

Gheorghe Ciocea, PhD., Eng., general manager at SC Termaexim SA Galati, obtained his scientific degree in thermal systems and equipments at „Dunarea de Jos” University of Galati and the topic of the $\mathrm{PhD}$ thesis was about optimisation of biomass combustion in small heating boilers. He has been working in energy area for 25 years. The main areas of interests are: steam boiler design and optimisation, heating systems design, combustion, renewable energy and techniques for air pollution control.

Address: 23 Petru Groza St., 800423 Galati, Romania. Phone: +400236470 870; Fax: +400236470669 E-mail: termaexim@yahoo.com

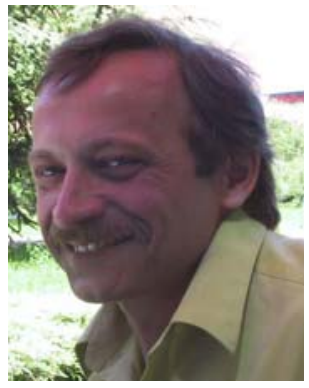

Florin Popescu, PhD. Eng., professor, "Dunarea de Jos" University of Galati, Department of Thermal Systems \& Environmental Engineering has been member of Mechanical Engineering Faculty since 1990. The main research areas are experimental and computational fluid dynamics, computational combustion, and computational heat transfer. $\mathrm{He}$ participated in many international and national research and academic projects.

E-mail: florin.popescu@ugal.ro 